Article

\title{
In Search of the Healthy Immigrant Effect in Four West European Countries
}

\author{
Dina Maskileyson ${ }^{1, *}$, Moshe Semyonov ${ }^{2}$ and Eldad Davidov ${ }^{1,3}$ \\ ${ }^{1}$ Institute of Sociology and Social Psychology, University of Cologne, 50923 Cologne, Germany; \\ E-Mail: dmaskile@uni-koeln.de (D.M.), e.davidov@uni-koeln.de (E.D.) \\ 2 Department of Sociology and Anthropology, Tel Aviv University, 6997801 Tel-Aviv, Israel; E-Mail: moshes@post.tau.ac.il \\ ${ }^{3}$ University Research Priority Program "Social Networks," University of Zurich, Zurich, Switzerland \\ * Corresponding author
}

Submitted: 30 June 2019 | Accepted: 27 November | Published: 27 December 2019

\begin{abstract}
The present research examines whether the 'healthy immigrant effect' thesis observed in the American context prevails also in the West European context. According to this thesis, immigrants are likely to be healthier than comparable nativeborn. Data for the analysis are obtained from the Generations and Gender Survey for the following countries: Austria, France, Germany, and the Netherlands. Ordered logit regression models are estimated to compare the health of immigrants with the native-born population. The findings reveal that in all countries, immigrants tend to report poorer health than comparable third generation native-born Europeans, and that health disparities between second and third generation are smaller than health disparities between first-generation members and native-born regardless of second- or thirdgeneration membership. The findings in the West-European countries do not lend support to the healthy immigrant effect. We attribute the differences between the United States and the West European countries to differential selection processes and differences in healthcare policies.
\end{abstract}

\section{Keywords}

comparative health; generation studies; healthy immigrant effect; immigrants; United States; Western Europe

\section{Issue}

This article is part of the issue "Immigration from the Migrants' Perspective" edited by Alice Ramos (Institute of Social Sciences, Portugal), Eldad Davidov (University of Cologne, Germany/University of Zurich, Switzerland), Peter Schmidt (University of Giessen, Germany), Marta Vilar Rosales (Institute of Social Sciences, Portugal) and Dina Maskileyson (University of Cologne, Germany).

(C) 2019 by the authors; licensee Cogitatio (Lisbon, Portugal). This article is licensed under a Creative Commons Attribution 4.0 International License (CC BY).

\section{Introduction}

Scholars have long observed that immigrants in the United States and in other traditional immigrant societies (i.e., Canada and Australia) tend to be healthier than comparable native-born populations (Cunningham, Ruben, \& Narayan, 2008; Goldman et al., 2014; McDonald \& Kennedy, 2004). Immigrants' health advantage is most evident shortly after arrival, but the health of immigrants tends to converge with that of the nativeborn with the passage of time (McDonald \& Kennedy, 2004; Ronellenfitsch \& Razum, 2004). The health of chil- dren of immigrants (i.e., second generation) is likely to be poorer than that of the first-generation and to converge with that of the third generation (and beyond) the native-born (Singh \& Siahpush, 2002). The patterns of health disparities that were observed in the United States (and other immigrant societies such as Australia and Canada) are referred to in the literature as 'the healthy immigrant effect' (or 'the Hispanic paradox' in the case of Mexican immigrants; Kennedy, McDonald, \& Biddle, 2006). Surprisingly, however, whereas the literature on the healthy immigrant effect in the United States has become substantial, relatively little is known 
on health disparities between immigrants and natives in Europe (for notable exceptions see Darmon \& Khlat, 2001; Razum, Zeeb, Akgün, \& Yilmaz, 1998). Indeed, it is not clear from previous studies whether the differences across nations are a result of nation-specific characteristics (of the host country or the country of origin). For example, it is not clear whether and to what extent differences between the context of country of origin and the context of country of destination (e.g., level of economic resources and accessibility to quality healthcare services) affects the size of the disparities between immigrants and the native-born. Using data from four national samples, we aim to evaluate whether the healthy immigrant effect that has been observed in the United States prevails in four Western European countries, Austria, France, Germany, and the Netherlands, or whether it is dependent on the unique conditions associated with differences between country of origin and country of destination.

\section{Previous Research}

\subsection{Explaining the Healthy Immigrant Effect}

Two alternative-but by no means contradictoryexplanations have been advanced in the literature for understanding why first-generation immigrants tend to be healthier than the native-born population. The first focuses on positive self-selection of immigrants. According to the 'selection hypothesis,' the health advantage of first-generation immigrants is attributed to positive health selection whereby healthier (vs. unhealthy) chose to migrate. Therefore, immigrants are likely to be, on average, healthier than the population of the country of origin and often healthier than the population of the host country (e.g., Jasso, Massey, Rosenzweig, \& Smith, 2004; Martinez, Aguayo-Tellez, \& Rangel-Gonzalez, 2015).

The positive health selection hypothesis was repeatedly supported in the context of American society by a large number of studies for various groups of immigrants. For example, positive health selection (according to which immigrants are healthier than comparable native-born) was observed for Hispanics (e.g., Martinez et al., 2015), for Asians and Pacific Islanders (e.g., Frisbie, Cho, \& Hummer, 2001), and for immigrants from the former Soviet Union (Mehta \& Elo, 2012). Likewise, Singh and Siahpush (2002) found that risk for all causes of mortality and specific causes of mortality, morbidity, and health problems is lower among immigrants (belonging to various ethnic groups) than among comparable nativeborn citizens. Akresh and Frank (2008) found that selfreported health is higher among immigrants than among the native-born both in the United States and in country of origin (except for the case of refugees).

The second explanation for the better health of immigrants that was advanced in the literature is known as the 'salmon bias' effect (e.g., Abraído-Lanza, Dohrenwend, Ng-Mak, \& Turner, 1999; Lu \& Qin, 2014; Martinez et al.,
2015). This explanation should not be viewed as contradictory to the 'positive health selection hypothesis' but rather as complementary. The logic embodied in the salmon bias thesis contends that immigrants with poorer health are more likely than healthy immigrants to return to country of origin. It should be noted, however, that the body of research that examined the salmon bias effect is much smaller than the research on the positive selection effect. In addition, the body of research on salmon bias effect has focused almost exclusively on Latino immigrants in the United States (Palloni \& Arias, 2004) mostly due to difficulties in tracking returning immigrants and in obtaining high quality reliable data in a wide-ranging number of countries. It should be noted, however, that most studies on the issue have provided, in one way or another, some support for the salmon effect (Riosmena, Wong, \& Palloni, 2013; Turra \& Elo, 2008).

Recently, in a systematic and detailed analysis of data on Mexican returnee migrants between 2005 and 2012, Arenas, Goldman, Pebley, and Teruel (2015) found that health of returnee immigrants is significantly poorer than that of stayers even after controlling for a variety of potential covariates including demographic characteristics, economic status, family ties, and characteristics of origin and destination. Yet despite the general support for the salmon-bias hypothesis, several researchers have questioned its impact on the overall better health of immigrants. For example, it was argued that the salmon bias cannot account for the lower mortality rates among Cubans and Puerto Ricans in the United States (AbraídoLanza et al., 1999) or Turks and other international immigrants in Germany (Razum et al., 1998; Wallace \& Kulu, 2014).

The evidence for the impact of generational status on health among immigrants and their offspring is quite limited, mostly due to the small number of studies on the topic (Acevedo-Garcia, Bates, Osypuk, \& McArdle, 2010). The few existing studies, however, reveal meaningful differences between first- and secondgeneration immigrants (Guendelman \& Abrams, 1995; Guendelman, Gould, Hudes, \& Eskenazi, 1990). These studies show that first-generation (foreign-born) immigrants, despite the deterioration in their general health prospects over time, still enjoy better health than nativeborn populations (Acevedo-Garcia et al., 2010). The second generation (native-born offspring of immigrants) and the 1.5-generation (foreign-born immigrants who migrated to the host country at a young age) are more likely to narrow the health-gap with the native population (i.e., third generation native-born children of native-born parents; see Acevedo-Garcia et al., 2010). For example, Guendelman et al., (1990) observed generational differences in low birthweight among women of Mexican origin with first-generation having a much smaller rate of low birthweight than second-generation immigrants. In another study, Guendelman and Abrams (1995) pointed out that as compared to the second 
generation, first-generation Mexican women stand a markedly lower risk of eating poor dietary food. The nutrient intake of second-generation women resembles that of white non-Hispanic women. Apparently, the few studies, particularly in the United States, that compared the first and second generation suggest that health of first-generation immigrants tends to be better than that of second-generation immigrants and of that of other native-born populations.

\subsection{Immigration and Health Outside the United States}

The overwhelming majority of research on the healthy immigrant effect has focused on American society. Yet the few studies that focused health disparities between immigrants and native-born population in traditional immigrant societies other than the United States (i.e., Canada and Australia) lend general support to the healthy immigrant effect thesis. For example, researchers observed that recently arrived immigrants in Canada and Australia are less likely to be diagnosed with chronic conditions than comparable native-born citizens (Biddle, Kennedy, \& McDonald, 2007; McDonald \& Kennedy, 2004). They also observed that health disparities between the immigrant and the native-born populations tend to decline with the passage of time in the host country (Biddle et al., 2007; McDonald \& Kennedy, 2004). Indeed, patterns of health disparities that were detected in Canada and Australia are highly similar to those observed in the United States and in line with the healthy immigrant effect thesis.

Additional support for the positive health selection of immigrants was recently provided by Kennedy, Kidd, McDonald, and Biddle (2015) who utilized data from four major immigrant recipient countries: the United States, Canada, the United Kingdom, and Australia. The researchers compared the health of immigrants with that of their compatriots who have no intention to immigrate. The findings revealed that the health of immigrants was better than that of those who stayed in the home country. Indeed, the body of research on the topic lends firm support to the positive health selection thesis revealing that when compared to native-born citizens, firstgeneration immigrants not only have substantially lower risks of smoking, drinking, obesity, hypertension, and chronic diseases but also a lower risk of mortality from almost all causes of death (Kennedy et al., 2015).

In Israel, however, where immigration (of Jewish people) is not restricted and where the criterion for admission is based on ancestry (and not on other criteria such as age, professional skills, or health), the findings differ sharply from those reported in the United States, Canada, or Australia. Research on recent immigrants in Israel refer to the 'sick immigrant effect' and reveal that illnesses, such as ischemic heart disease, diabetes, hypertension, chronic diseases, limiting symptoms, and self-reported (poor) health are significantly more abundant among immigrants than among comparable native- born Israelis (e.g., Constant, García-Muñoz, Neuman, \& Neuman, 2015). Indeed, these findings suggest that immigration policies as well as restrictions and regulations associated with immigration policies might affect selection of immigrants into host societies and their health.

\subsection{Immigration and Health in European Countries}

The body of research on health disparities between immigrants and the native-born population in European societies has also grown in recent years. The findings reported by studies in various European societies, however, are neither uniform nor conclusive and at times even contradictory (e.g., Boulogne, Jougla, Breem, Kunst, \& Rey, 2012; Darmon \& Khlat, 2001; Guendelman et al., 1990; Razum \& Rohrmann, 2002). In some European countries, immigrants were found to be healthier than the nativeborn but in others the native-born were found to be healthier than immigrants. More specifically, in France, for example, researchers detected the healthy immigrant effect (e.g., Boulogne et al., 2012; Darmon \& Khlat, 2001; Guendelman et al., 1990) while observing lower mortality rates and a higher life expectancy among groups of foreign-born as compared to the native-born population. In Germany, a longitudinal study by Elkeles and Seifert (1996) revealed that the foreign-born population reported lower rates of chronic illness and long-term health problems than the working-age German population. Likewise, Razum and Rohrmann (2002) and Razum et al. (1998) reported a lower mortality risk and better health among immigrants of Mediterranean origins and among Turks as compared to native-born Germans. However, Ronellenfitsch and Razum (2004), who relied on health satisfaction as an indicator of health, found that young immigrants from Eastern Europe, despite their initial health advantage (compared to older immigrants and native-born Germans), have a high risk of deteriorating health (despite the improvement in socioeconomic status over the years). The results observed in Austria (Sardadvar, 2015) indicate that the health of immigrants from Turkey and Yugoslavia (and to a lesser extent from new member states of the EU or other parts of the world) is poorer than the health of native-born Austrians even after controlling for differences in socioeconomic status.

There are several plausible explanations as to why the findings for European countries may differ from the findings for the United States or from other traditional immigrant societies such as Canada and Australia. First, the healthcare system in the United States is much more expensive and less accessible than the health systems of most West European countries (Organization for Economic Co-operation and Development [OECD], 2016). Consequently, the average health of Europeans is considerably higher than the average health of US-Americans (Maskileyson, 2014; Semyonov, LewinEpstein, \& Maskileyson, 2013), and immigrants to European countries are less likely to be concerned with 
health constraints when considering migration. Second, the visa policy in the United States is much more restrictive and the refusal rate for initial applications is higher as compared to Western Europe (OECD, 2019). Health criteria for admission of (documented) immigrants to the United States are much more rigid and restrictive than health criteria for admission to Western Europe. Regardless of their immigrant category, authorized immigrants are selected for entry into the United States based on their health conditions (CDC, 2014). In other words, different health considerations operate in the selection process of immigrants to the United States as compared to West European countries. Moreover, immigrants to Western Europe originate from countries that are substantially different from the countries of origin of immigrants to the United States (OECD, 2019). Whereas in the United States the main countries of immigrants' origin are Mexico (25\%), India (6\%), China (5\%), in the four Western European countries under study, these are other European countries, Turkey, or Maghreb countries. Specifically, in the Netherlands, the main countries of birth of the immigrants are Turkey (9\%), Suriname $(8 \%)$, and Morocco (8\%); in Germany these are Poland (13\%), Turkey (10\%), and Russia (8\%); in Austria these are Germany (13\%), Bosnia and Herzegovina (10\%), and Turkey (9\%); and in France the countries are Algeria (17\%), Morocco (12\%), and Portugal (8\%; OECD, 2019). In addition, the vast majority of the immigrants in the United States consists of family reunification immigrants $(72.9 \%)$, whereas only $5.8 \%$ are labor migrants and $13 \%$ humanitarian migrants (OECD, 2019). In the four European countries in this study, the large share of the immigrant population consists of immigrants benefitting from free mobility (e.g., $61.4 \%$ in the Netherlands, $58.8 \%$ in Germany). That is to say, in contrast to the United States, in Europe, immigrants enjoy extensive rights to free movement. Comparatively, a much lower share of immigrants in Western Europe immigrate due to family reunification reasons (e.g., $13.4 \%$ in Germany, and only $9.7 \%$ in Austria). The share of labor migrants in these four countries ranges from $5.1 \%$ (in Austria) to $12.7 \%$ (in the Netherlands), a proportion that is, on average, higher than in the United States (OECD, 2019).

In the present article we address the following two major questions: First, whether and to what extent do patterns of health disparity between immigrants and the native-born population vary by generational status (first, second, and third and higher generations)? Second, whether and to what extent do economic conditions in the country of origin affect health disparities between immigrants and the native-born population? In the current study, due to data limitations, we examine subjective health disparities between natives and immigrants. Subjective health has been shown to be a powerful predictor of life expectancy and to correlate positively with objective health (Williams, Pham-Kanter, \& Leitsch, 2009). In terms of these questions, we propose the following hypotheses:
Hypothesis 1: We expect first-generation immigrants to have comparable or worse subjective health than second- and third-generation immigrants in the four West European countries under the study.

Hypothesis 2: We expect economic conditions in the immigrant's country of origin to affect the subjective health between immigrants and natives. Specifically, with better economic conditions in country of origin, smaller subjective health disparities are expected between immigrants and native-born citizens. Immigrants who arrived from countries with better economic conditions are expected to display better subjective health levels as compared to immigrants from countries with worse economic conditions.

\section{Data, Variables, and Method}

\subsection{Data}

Data for the analysis were obtained from wave 1 of the Generations and Gender Survey (GGS) collected in 2002-2009 (United Nations, 2005). The GGS (n.d.) database represents a three-wave panel study conducted at three-year time intervals across 19 developed countries. The GGS contains information about a range of issues including fertility decision making, combining employment and parenthood, intergenerational solidarity, retirement, migration, and health. The target population in a country is the resident non-institutionalized population aged 18 to 79 years at the time of the first wave. A probability sampling procedure was applied in all countries. The exact method used was allowed to vary across countries based on the availability and cost-effectiveness of different sampling frames (for details about sampling strategy in each country, see Fokkema, Kveder, Hiekel, Emery, \& Liefbroer, 2016). We restricted the analysis to countries with at least 300 first-generation immigrants aged 26 years and older (in Austria, the maximum age of the collected data is 45). The four countries included in the study that met the criteria are Austria $(3,892)$, France $(8,731)$, Germany $(8,052)$, and the Netherlands $(7,219)$. The total number of cases for the analysis amount to 27,894 individuals.

The response rates in four selected countries were as follows: Austria-64.6\%, Germany-55.4\%, the Netherlands-44.6\%, and France-66.8\% (Fokkema et al., 2016). Higher non-response rate in the Netherlands might be partly explained by the fact that the Dutch GGS was conceived as a multi-person survey, and some respondents may have refused cooperation in advance because they did not want to involve multiple family members (Fokkema et al., 2016). Generally, however, the response rates in the GGS are found to be comparable to those in other cross-national surveys (Fokkema et al., 2016). 


\subsection{Variables}

The dependent variable used in the analysis is respondents' self-reported perceived general health. The original variable included five categories. Due to the very small number of cases in the categories 'bad' and 'very bad' they were combined into one category 'fair health and below.' Health status was recoded into three ordinal categories: 'very good health,' 'good health,' and 'fair health and below.' We rely on a single indicator of subjective health because no objective measures of health were available in the data set. It should be noted, however, that a series of studies have repeatedly demonstrated that subjective and objective indicators of health are highly interrelated and that subjective indicators of health can be viewed as valid and reliable measures of health status (Ferraro \& Farmer, 1999; Laumann, Paik, \& Rosen, 1999; Østbye et al., 2006; Williams et al., 2009).

To capture differences in generational and nativity status, we included a set of dummy variables classifying respondents according to place of birth of both respondents and their parents: First-generation pertains to immigrants not born in the country (hereafter FG); secondgeneration pertains to individuals who were born in the country but with at least one parent who is a foreignborn (hereafter SG). Third generation and beyond and native-born include individuals born in the country with both parents born in the country (hereafter TG). In the multivariate analysis, TG serves as a benchmark category. Notably, data on the years since migration variable were not available for the Netherlands. Therefore, to maintain comparability of the models across countries, we did not include it in the analysis of the other three countries. It should be noted, however, that the present analysis is not concerned with testing 'bad assimilation,' but with differences in subjective health across natives and different generations of immigrants. A robustness test of the models in the three countries, Austria, France, and Germany, which included the number of years since migration in the models provided similar results and can be obtained from the first author upon request.

A series of sociodemographic variables are used as control variables. Three levels of educational achievement were distinguished using the International Standard Classification of Education (ISCED; UNESCO Institute for Statistics, 2012), and a dummy variable was created for distinguishing between secondary education not completed (hereinafter, low education) and academic education (hereinafter, high education). The second variable, intermediate education (completed secondary or post-secondary non-academic), is the comparison group. The control variables that are relevant for health include: age of respondent (in years), gen$\operatorname{der}($ male $=1$ vs. female $=0$ ), labor force status (with dummy variables indicating whether unemployed $=1$, professional, technician or manager $=1$; clerk; bluecollar worker $=1 \mathrm{vs}$. not in the labor force $=0$ ), household size (number of persons), marital status (married $=1$ vs. never married, divorced and widowed $=0$ ), and area of residence (urban area $=1$ vs. peripheral and rural areas $=0$ ). Previous studies have shown that health is worse among older, less educated, unemployed, not married, and non-urban individuals and persons of lower socioeconomic standing (Eikemo, Bambra, Joyce, \& Dahl, 2008; Semyonov et al., 2013). To capture contextual differences stemming from socioeconomic conditions in the country of origin, we used each country's PPP-adjusted gross national income (GNI) per capita of 2014 measured in rank points given by the World Bank (with higher values of GNI implying a higher rank; for more information see World Bank Group, 2014). See Table A1 in the Annex for a complete list of variable names and measurements.

\subsection{Method}

The analysis is organized as follows. First, we provide descriptive statistics characterizing patterns of immigrant subjective health disparities across generations by country of destination. Second, we conduct multivariate ordered logit regression analysis to examine whether health disparities hold when taking into consideration variations in socioeconomic and sociodemographic characteristics of the respondents and as well as socioeconomic status of countries of origin (as measured by GNI). This part of the analysis is divided into two subsections: (1) country-specific ordered regression models predicting reported health by country of destination; and (2) ordered regression predicting good general health status by pooling the four countries into one pooled sample. The ordered logit regression model predicts the odds of being in good health as a function of individual-level characteristics plus GNI of country origin characteristics. The model can be represented by the following equation:

$$
\ln \left[\frac{p(y \leq j)}{p(y>j)}\right]=\alpha_{j}-\sum_{k=1}^{k} \beta_{k} X_{k} \text { for } j=1 \text { to } j=j-1
$$

Where $\ln [p(y \leq j) / p(y>j))]$ is the natural logarithm of the probability of belonging to a certain category $(j)$ or lower category of health status, divided by the probability of belonging to the higher category of health status. In other words, it is the natural logarithm of the probability that person has very good health, as opposed to the probability that he/she does not have good health. $\alpha_{j} \beta_{o j}$ is the intercept, whereas $X_{k}$ are independent variables representing personal characteristics. $\beta_{k} \beta_{4 j}$ are the vectors of the coefficients.

In model 1, health is taken as a function of FG and SG (as compared to TG) plus age. In model 2, we include a set of sociodemographic attributes as control variables on health. The GNI of immigrant's country of origin was introduced into model 3 as an indicator of economic and social conditions to which immigrants were exposed when growing up. The GNI of immigrant's country of origin was included in this model as an interaction term to estimate the impact of country of origin on health 
disparities between FG and the native-born population (both SG and TG). GNI of country of birth was centered around the sample mean to overcome the problem of multicollinearity between country of origin and FG. To provide further affirmation of the country-specific findings, we conducted an additional analysis with all four countries pooled into one data set.

\section{Analysis and Findings}

Figure 1 displays the health differences of the population by generation and by country. The data reveal both crosscountry variations and similarities. Generally speaking, subjective health is highest in the Netherlands where over $80 \%$ of TG reported good health. In Austria, the high level of good health ( $90 \%$ among TG) might reflect the young age of the Austrian sample (the upper age limit to participate in the GGS in Austria is 45 years). France and Germany are characterized by lower levels of good health in comparison to both the Netherlands and Austria. In all countries, except for Germany, the proportion of FG immigrants who report good health is lower than the proportions reported by SG or TG. In Germany, FG is more likely to report good health than TG native Germans and SG reports similar health to TG native-born.

The findings reveal that patterns of health disparities between FG and TG in France, Austria, and the Netherlands are not in line with expectations derived from the healthy immigrant effect thesis and are drastically different from the pattern observed in the United States: In the three countries, health of FG immigrants is poorer than that of TG. Only in Germany do FG immigrants report better health than TG (but this is a result of age differentials, as will be shown later). The findings with regard to SG are less consistent. In Germany and Austria, subjective health of SG seems to converge with that of TG, but in France SG reported better health than
TG, and in the Netherlands SG reported poorer subjective health than TG.

The four national samples differ not only in subjective health but also in sociodemographic characteristics. Table 1 displays characteristics of the population by generation and by country. FG immigrants are, on average, considerably younger than TG in Germany and the Netherlands but similar in age to TG in France and Austria. In all countries, TG natives are least likely to be unemployed while FG immigrants are most likely to be unemployed. Likewise, in all countries, FG immigrants are overrepresented in the low educational category as compared to both the SG and TG. However, in France, the proportion of FG who attained academic education is considerably lower than that of TG. By way of comparison, in all countries except Germany, SG has the highest proportion of persons with academic education. In addition, immigrants are more likely to reside in urban areas (except in the Netherlands) and to have larger families.

Although interesting, it is not clear whether differences in reported health across generations can be attributed to differences in sociodemographic attributes of individuals. Thus, in Table 2 we estimate a series of country-specific ordered regression equations predicting reported health. The data in Equation 1 (Table 2) reveal that, in all countries, net of age, health reported by firstgeneration immigrants is significantly lower than that of TG, as evidenced by the negative coefficient of the FG. In France, the Netherlands, and Austria, the negative coefficient of FG (observed in Equation 1) remains negative and statistically significant in models 2 and 3 (which include sociodemographic controls). In Germany, the FG coefficient is reduced to the level of statistical insignificance. This finding implies that in Germany, unlike the other countries, health differences between FG and TG Germans can be fully attributed to age and socioeconomic differences between the groups.

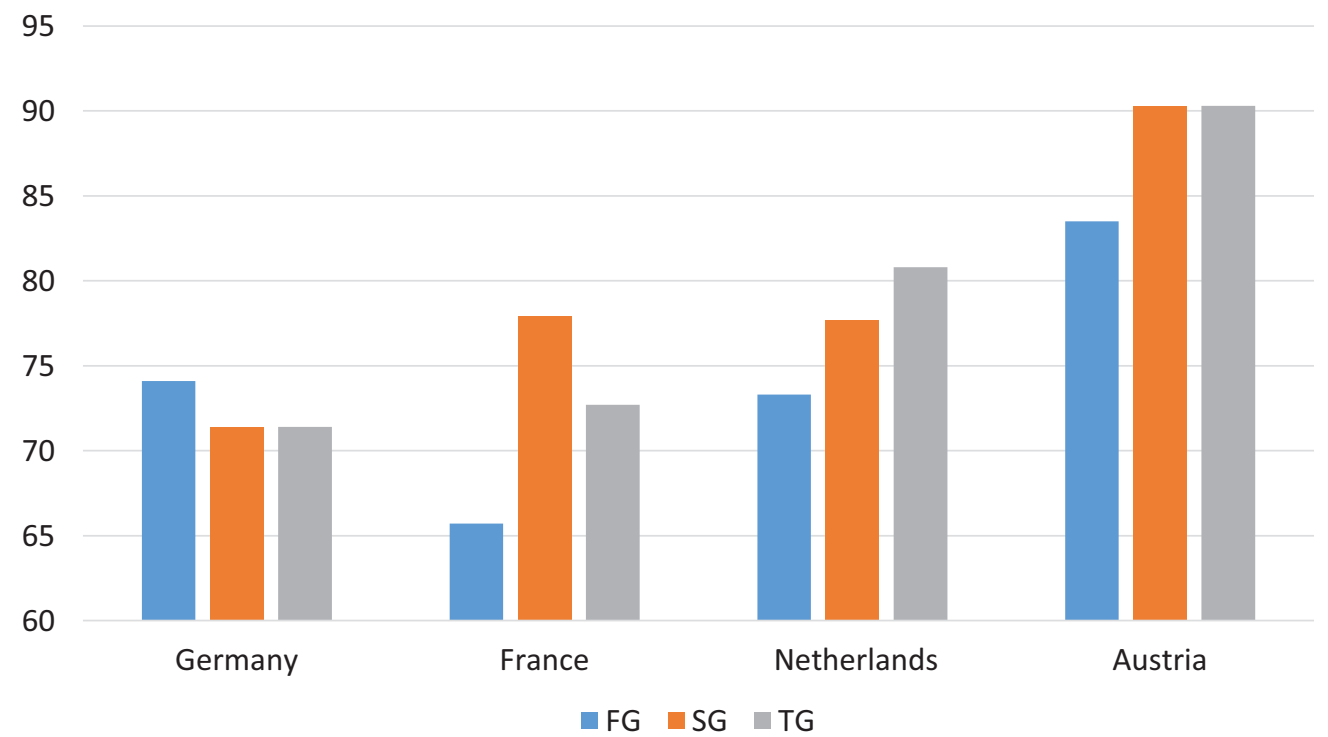

Figure 1. Percentage of individuals reporting to have good and very good general health by generation and by country. 
Table 1. Descriptive statistics by country of destination and generation, 26 years of age and older.

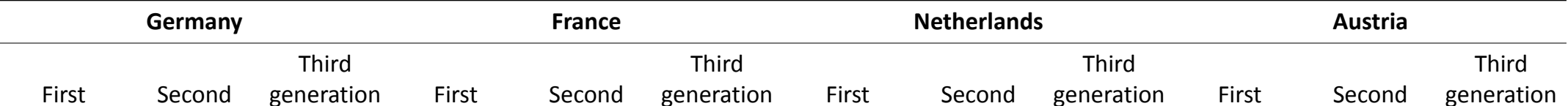

Variables

generation generation and above generation generation and above generation generation and above generation generation and above

\begin{tabular}{|c|c|c|c|c|c|c|c|c|c|c|c|c|}
\hline $\begin{array}{l}\text { Good and very good } \\
\text { general health, \% }\end{array}$ & 74.10 & 71.40 & 71.40 & 65.70 & 77.90 & 72.70 & 73.30 & 77.70 & 80.80 & 83.50 & 90.30 & 90.30 \\
\hline $\begin{array}{l}\text { Age of respondent, } \\
\text { mean }(S D)^{*}\end{array}$ & $\begin{array}{c}43.97 \\
(12.37)\end{array}$ & $\begin{array}{c}44.44 \\
(13.33)\end{array}$ & $\begin{array}{c}51.20 \\
(14.55)\end{array}$ & $\begin{array}{c}51.10 \\
(13.69)\end{array}$ & $\begin{array}{c}45.23 \\
(14.49)\end{array}$ & $\begin{array}{c}50.29 \\
(14.85)\end{array}$ & $\begin{array}{c}43.44 \\
(12.32)\end{array}$ & $\begin{array}{c}49.00 \\
(15.21)\end{array}$ & $\begin{array}{c}49.18 \\
(14.32)\end{array}$ & $\begin{array}{l}36.37 \\
(5.76)\end{array}$ & $\begin{array}{l}36.66 \\
(5.74)\end{array}$ & $\begin{array}{l}36.45 \\
(6.03)\end{array}$ \\
\hline Male, \% & 53.10 & 50.60 & 48.30 & 55.50 & 47.70 & 46.00 & 50.00 & 50.00 & 45.60 & 44.90 & 44.00 & 47.80 \\
\hline Lower education, \% & 32.80 & 13.30 & 11.70 & 46.50 & 28.40 & 33.60 & 42.80 & 32.80 & 36.40 & 22.90 & 12.30 & 7.10 \\
\hline Academic education, \% & 13.70 & 24.40 & 24.90 & 25.30 & 32.00 & 24.80 & 31.50 & 34.40 & 33.60 & 18.70 & 25.60 & 21.40 \\
\hline Unemployed, \% & 11.90 & 13.70 & 6.70 & 10.70 & 8.80 & 5.30 & 8.70 & 4.30 & 2.50 & 6.90 & 2.20 & 2.70 \\
\hline $\begin{array}{l}\text { Professionals, technicians, } \\
\text { and managers, \% }\end{array}$ & 2.00 & 11.30 & 11.20 & 16.20 & 30.70 & 23.30 & 26.90 & 34.10 & 37.60 & 24.70 & 46.20 & 39.30 \\
\hline Clerks, \% & 17.20 & 31.60 & 30.30 & 7.60 & 13.70 & 13.70 & 12.30 & 11.90 & 11.20 & 20.50 & 27.10 & 26.00 \\
\hline Blue collar occupations, \% & 42.60 & 17.80 & 13.00 & 23.30 & 18.20 & 18.50 & 16.90 & 8.90 & 9.10 & 29.70 & 19.10 & 24.10 \\
\hline $\begin{array}{l}\text { Household size including } \\
\text { respondent, mean (SD) }\end{array}$ & $\begin{array}{c}3.32 \\
(1.45)\end{array}$ & $\begin{array}{c}2.62 \\
(1.30)\end{array}$ & $\begin{array}{c}2.44 \\
(1.24)\end{array}$ & $\begin{array}{c}3.01 \\
(1.56)\end{array}$ & $\begin{array}{c}2.73 \\
(1.40)\end{array}$ & $\begin{array}{c}2.58 \\
(1.26) \\
\end{array}$ & $\begin{array}{c}3.05 \\
(1.70)\end{array}$ & $\begin{array}{c}2.33 \\
(1.28) \\
\end{array}$ & $\begin{array}{c}2.57 \\
(1.37) \\
\end{array}$ & $\begin{array}{c}3.24 \\
(1.40) \\
\end{array}$ & $\begin{array}{c}2.94 \\
(1.38) \\
\end{array}$ & $\begin{array}{c}3.05 \\
(1.40) \\
\end{array}$ \\
\hline Married, \% & 80.90 & 60.00 & 64.00 & 67.60 & 51.80 & 59.80 & 60.40 & 52.60 & 62.20 & 62.90 & 56.30 & 46.50 \\
\hline Lives in urban area, \% & 41.20 & 44.30 & 41.40 & 63.30 & 64.80 & 67.80 & 71.00 & 57.30 & 43.80 & 80.80 & 78.00 & 53.70 \\
\hline $\begin{array}{l}\text { GNI rank of country of birth } \\
\text { (higher value indicates } \\
\text { higher rank), mean (SD) }\end{array}$ & $\begin{array}{l}141.67 \\
(11.39)\end{array}$ & - & - & $\begin{array}{l}140.26 \\
(24.17)\end{array}$ & - & - & $\begin{array}{l}127.25 \\
(44.85)\end{array}$ & $\begin{array}{l}- \\
-\end{array}$ & $\begin{array}{l}- \\
-\end{array}$ & $\begin{array}{l}125.35 \\
(41.08)\end{array}$ & $\begin{array}{l}- \\
-\end{array}$ & $\begin{array}{l}- \\
-\end{array}$ \\
\hline $\begin{array}{l}\text { GNI rank of country of } \\
\text { destination (higher value } \\
\text { indicates higher rank), } \\
\text { mean (SD) }\end{array}$ & $\begin{array}{r}185.00 \\
(0.00)\end{array}$ & $\begin{array}{r}185.00 \\
(0.00)\end{array}$ & $\begin{array}{r}185.00 \\
(0.00)\end{array}$ & $\begin{array}{r}172.00 \\
(0.00)\end{array}$ & $\begin{array}{r}172.00 \\
(0.00)\end{array}$ & $\begin{array}{r}172.00 \\
(0.00)\end{array}$ & $\begin{array}{r}186.00 \\
(0.00)\end{array}$ & $\begin{array}{r}186.00 \\
(0.00)\end{array}$ & $\begin{array}{r}186.00 \\
(0.00)\end{array}$ & $\begin{array}{r}182.00 \\
(0.00)\end{array}$ & $\begin{array}{r}182.00 \\
(0.00)\end{array}$ & $\begin{array}{r}182.00 \\
(0.00)\end{array}$ \\
\hline Observations (not weighted) & 417 & 448 & 7,187 & 990 & 907 & 6,834 & 387 & 308 & 6,524 & 669 & 290 & 2,933 \\
\hline
\end{tabular}

Notes: Mean coefficients; SD in parentheses; cases are weighted according to country-specific population weight; ${ }^{*}$ In Austria, the maximum age of respondents is 46 years. 
Table 2. Ordered regression predicting good general health status by country of destination (dependent variable is self-perceived health, $1-3,3=$ very good health).

\begin{tabular}{|c|c|c|c|c|c|c|c|c|c|c|c|c|}
\hline \multirow[b]{2}{*}{ Variables } & \multicolumn{3}{|c|}{ Germany } & \multicolumn{3}{|c|}{ France } & \multicolumn{3}{|c|}{ Netherlands } & \multicolumn{3}{|c|}{ Austria } \\
\hline & (1) & $(2)$ & (3) & (1) & $(2)$ & (3) & $(1)$ & (2) & (3) & (1) & $(2)$ & (3) \\
\hline \multicolumn{13}{|l|}{ Generation $^{a}$} \\
\hline First-generation ( = 1) & $\begin{array}{c}-0.376^{* *} \\
(0.092)\end{array}$ & $\begin{array}{c}-0.121 \\
(0.098)\end{array}$ & $\begin{array}{c}0.086 \\
(0.117)\end{array}$ & $\begin{array}{c}-0.252^{* *} \\
(0.061)\end{array}$ & $\begin{array}{c}-0.185^{* *} \\
(0.063)\end{array}$ & $\begin{array}{c}-0.154^{*} \\
(0.064)\end{array}$ & $\begin{array}{c}-0.602 * * \\
(0.102)\end{array}$ & $\begin{array}{c}-0.462^{* *} \\
(0.104)\end{array}$ & $\begin{array}{c}-0.410^{* *} \\
(0.105)\end{array}$ & $\begin{array}{c}-0.595^{* *} \\
(0.077)\end{array}$ & $\begin{array}{c}-0.467^{* *} \\
(0.083)\end{array}$ & $\begin{array}{c}-0.457^{* *} \\
(0.084)\end{array}$ \\
\hline Second-generation $(=1$ ) & $\begin{array}{c}-0.305^{* *} \\
(0.094)\end{array}$ & $\begin{array}{c}-0.243^{*} \\
(0.096)\end{array}$ & $\begin{array}{c}-0.241^{*} \\
(0.096)\end{array}$ & $\begin{array}{c}-0.046 \\
(0.067)\end{array}$ & $\begin{array}{c}-0.038 \\
(0.067)\end{array}$ & $\begin{array}{c}-0.036 \\
(0.067)\end{array}$ & $\begin{array}{c}-0.189 \\
(0.114)\end{array}$ & $\begin{array}{c}-0.151 \\
(0.115)\end{array}$ & $\begin{array}{c}-0.152 \\
(0.115)\end{array}$ & $\begin{array}{c}-0.159 \\
(0.121)\end{array}$ & $\begin{array}{c}-0.179 \\
(0.124)\end{array}$ & $\begin{array}{c}-0.180 \\
(0.124)\end{array}$ \\
\hline Age & $\begin{array}{c}-0.068^{* *} \\
(0.002)\end{array}$ & $\begin{array}{c}-0.061 * * \\
(0.002)\end{array}$ & $\begin{array}{c}-0.061^{* *} \\
(0.002)\end{array}$ & $\begin{array}{c}-0.050^{* *} \\
(0.001)\end{array}$ & $\begin{array}{c}-0.033^{* *} \\
(0.002)\end{array}$ & $\begin{array}{c}-0.033^{* *} \\
(0.002)\end{array}$ & $\begin{array}{c}-0.031^{* *} \\
(0.002)\end{array}$ & $\begin{array}{c}-0.016^{* *} \\
(0.002)\end{array}$ & $\begin{array}{c}-0.016^{* *} \\
(0.002)\end{array}$ & $\begin{array}{c}-0.072^{* *} \\
(0.005)\end{array}$ & $\begin{array}{c}-0.079 * * \\
(0.006)\end{array}$ & $\begin{array}{c}-0.079 * * \\
(0.006)\end{array}$ \\
\hline Male $^{b}(=1)$ & $\begin{array}{l}- \\
-\end{array}$ & $\begin{array}{c}-0.055 \\
(0.047)\end{array}$ & $\begin{array}{c}-0.059 \\
(0.047)\end{array}$ & $\begin{array}{l}- \\
-\end{array}$ & $\begin{array}{c}0.155^{* *} \\
(0.043)\end{array}$ & $\begin{array}{c}0.153^{* *} \\
(0.043)\end{array}$ & $\begin{array}{l}- \\
-\end{array}$ & $\begin{array}{l}0.153^{* *} \\
(0.049)\end{array}$ & $\begin{array}{c}0.166^{* *} \\
(0.049)\end{array}$ & $\begin{array}{l}- \\
-\end{array}$ & $\begin{array}{c}0.161^{*} \\
(0.068)\end{array}$ & $\begin{array}{c}0.165^{*} \\
(0.068)\end{array}$ \\
\hline \multicolumn{13}{|l|}{ Education $^{\mathrm{c}}$} \\
\hline Lower education ( = 1) & $\begin{array}{l}- \\
-\end{array}$ & $\begin{array}{c}-0.555^{* *} \\
(0.072)\end{array}$ & $\begin{array}{c}-0.583^{* *} \\
(0.073)\end{array}$ & $\begin{array}{l}- \\
-\end{array}$ & $\begin{array}{c}-0.363^{* *} \\
(0.051)\end{array}$ & $\begin{array}{c}-0.362^{* *} \\
(0.051)\end{array}$ & $\begin{array}{l}- \\
-\end{array}$ & $\begin{array}{c}-0.278^{* *} \\
(0.059)\end{array}$ & $\begin{array}{c}-0.269^{* *} \\
(0.059)\end{array}$ & $\begin{array}{l}- \\
-\end{array}$ & $\begin{array}{c}-0.390^{* *} \\
(0.107)\end{array}$ & $\begin{array}{c}-0.377^{* *} \\
(0.108)\end{array}$ \\
\hline Academic education $(=1)$ & $\begin{array}{l}- \\
-\end{array}$ & $\begin{array}{c}0.386 * * \\
(0.056)\end{array}$ & $\begin{array}{c}0.394^{* *} \\
(0.056)\end{array}$ & $\begin{array}{l}- \\
-\end{array}$ & $\begin{array}{l}0.434^{* *} \\
(0.059)\end{array}$ & $\begin{array}{l}0.427^{* *} \\
(0.059)\end{array}$ & $\begin{array}{l}- \\
-\end{array}$ & $\begin{array}{l}0.206^{* *} \\
(0.060)\end{array}$ & $\begin{array}{l}0.208^{* *} \\
(0.060)\end{array}$ & $\begin{array}{l}- \\
-\end{array}$ & $\begin{array}{c}0.064 \\
(0.083)\end{array}$ & $\begin{array}{c}0.061 \\
(0.083)\end{array}$ \\
\hline \multicolumn{13}{|l|}{ Labor force status $^{d}$} \\
\hline Unemployed ( = 1) & $\begin{array}{l}- \\
-\end{array}$ & $\begin{array}{c}-0.389 * * \\
(0.096)\end{array}$ & $\begin{array}{c}-0.388^{* *} \\
(0.096)\end{array}$ & $\begin{array}{l}- \\
-\end{array}$ & $\begin{array}{c}-0.129 \\
(0.098)\end{array}$ & $\begin{array}{c}-0.134 \\
(0.098)\end{array}$ & $\begin{array}{l}- \\
-\end{array}$ & $\begin{array}{c}-0.069 \\
(0.143)\end{array}$ & $\begin{array}{c}-0.038 \\
(0.144)\end{array}$ & $\begin{array}{l}- \\
-\end{array}$ & $\begin{array}{c}-0.738^{* *} \\
(0.197)\end{array}$ & $\begin{array}{c}-0.738 * * \\
(0.197)\end{array}$ \\
\hline $\begin{array}{l}\text { Professionals, technicians, } \\
\text { and managers }(=1)\end{array}$ & $\begin{array}{l}- \\
-\end{array}$ & $\begin{array}{l}0.454^{* *} \\
(0.086)\end{array}$ & $\begin{array}{l}0.447^{* *} \\
(0.086)\end{array}$ & $\begin{array}{l}- \\
-\end{array}$ & $\begin{array}{l}0.672 * * \\
(0.072)\end{array}$ & $\begin{array}{l}0.678 * * \\
(0.073)\end{array}$ & $\begin{array}{l}- \\
-\end{array}$ & $\begin{array}{l}0.700 * * \\
(0.068)\end{array}$ & $\begin{array}{l}0.693 * * \\
(0.068)\end{array}$ & $\begin{array}{l}- \\
-\end{array}$ & $\begin{array}{l}0.432 * * \\
(0.121)\end{array}$ & $\begin{array}{l}0.425^{* *} \\
(0.121)\end{array}$ \\
\hline Clerks $(=1)$ & $\begin{array}{l}- \\
-\end{array}$ & $\begin{array}{l}0.334^{* *} \\
(0.065)\end{array}$ & $\begin{array}{l}0.334^{* *} \\
(0.065)\end{array}$ & $\begin{array}{l}- \\
-\end{array}$ & $\begin{array}{l}0.499 * * \\
(0.079)\end{array}$ & $\begin{array}{l}0.499 * * \\
(0.079)\end{array}$ & $\begin{array}{l}- \\
-\end{array}$ & $\begin{array}{l}0.583 * * \\
(0.083)\end{array}$ & $\begin{array}{l}0.583 * * \\
(0.083)\end{array}$ & $\begin{array}{l}- \\
-\end{array}$ & $\begin{array}{c}0.105 \\
(0.122)\end{array}$ & $\begin{array}{c}0.101 \\
(0.122)\end{array}$ \\
\hline Blue collar (=1) & $\begin{array}{l}- \\
-\end{array}$ & $\begin{array}{l}0.271^{* *} \\
(0.079)\end{array}$ & $\begin{array}{l}0.268^{* *} \\
(0.079)\end{array}$ & $\begin{array}{l}- \\
-\end{array}$ & $\begin{array}{l}0.392 * * \\
(0.072)\end{array}$ & $\begin{array}{l}0.402^{* *} \\
(0.072)\end{array}$ & $\begin{array}{l}- \\
-\end{array}$ & $\begin{array}{l}0.569 * * \\
(0.092)\end{array}$ & $\begin{array}{l}0.564^{* *} \\
(0.092)\end{array}$ & $\begin{array}{l}- \\
-\end{array}$ & $\begin{array}{c}0.054 \\
(0.125)\end{array}$ & $\begin{array}{c}0.055 \\
(0.125)\end{array}$ \\
\hline Household size & $\begin{array}{l}- \\
-\end{array}$ & $\begin{array}{c}0.013 \\
(0.022)\end{array}$ & $\begin{array}{c}0.008 \\
(0.022)\end{array}$ & $\begin{array}{l}- \\
-\end{array}$ & $\begin{array}{c}0.014 \\
(0.019)\end{array}$ & $\begin{array}{c}0.011 \\
(0.019)\end{array}$ & $\begin{array}{l}- \\
-\end{array}$ & $\begin{array}{c}0.038 \\
(0.021)\end{array}$ & $\begin{array}{c}0.044^{*} \\
(0.021)\end{array}$ & $\begin{array}{l}- \\
-\end{array}$ & $\begin{array}{l}0.010 \\
(0.027)\end{array}$ & $\begin{array}{c}0.010 \\
(0.027)\end{array}$ \\
\hline Married $^{\mathrm{e}}(=1)$ & $\begin{array}{l}- \\
-\end{array}$ & $\begin{array}{c}0.011 \\
(0.056)\end{array}$ & $\begin{array}{c}0.012 \\
(0.056)\end{array}$ & $\begin{array}{l}- \\
-\end{array}$ & $\begin{array}{c}0.119^{*} \\
(0.048)\end{array}$ & $\begin{array}{c}0.122^{*} \\
(0.048)\end{array}$ & $\begin{array}{l}- \\
-\end{array}$ & $\begin{array}{l}0.254^{* *} \\
(0.058)\end{array}$ & $\begin{array}{l}0.253^{* *} \\
(0.058)\end{array}$ & $\begin{array}{l}- \\
-\end{array}$ & $\begin{array}{l}0.216^{* *} \\
(0.076)\end{array}$ & $\begin{array}{l}0.221^{* *} \\
(0.076)\end{array}$ \\
\hline Lives in urban area ${ }^{f}(=1)$ & $\begin{array}{l}- \\
-\end{array}$ & $\begin{array}{l}0.129 * * \\
(0.045)\end{array}$ & $\begin{array}{l}0.120^{* *} \\
(0.045)\end{array}$ & $\begin{array}{l}- \\
-\end{array}$ & $\begin{array}{c}0.094 * \\
(0.044)\end{array}$ & $\begin{array}{c}0.098^{*} \\
(0.044)\end{array}$ & $\begin{array}{l}- \\
-\end{array}$ & $\begin{array}{c}-0.095^{*} \\
(0.047)\end{array}$ & $\begin{array}{c}-0.089 \\
(0.047)\end{array}$ & $\begin{array}{l}- \\
-\end{array}$ & $\begin{array}{c}-0.056 \\
(0.069)\end{array}$ & $\begin{array}{c}-0.050 \\
(0.069)\end{array}$ \\
\hline $\begin{array}{l}\text { GNI rank: country of birth } \\
\text { (centered)*Generation } 1\end{array}$ & $\begin{array}{l}- \\
-\end{array}$ & $\begin{array}{ll}- \\
-\end{array}$ & $\begin{array}{l}-0.026^{* *} \\
(0.008)\end{array}$ & $\begin{array}{l}- \\
-\end{array}$ & $\begin{array}{l}- \\
-\end{array}$ & $\begin{array}{c}-0.005^{*} \\
(0.002)\end{array}$ & $\begin{array}{l}- \\
-\end{array}$ & $\begin{array}{l}- \\
-\end{array}$ & $\begin{array}{l}0.008^{* *} \\
(0.002)\end{array}$ & $\begin{array}{l}- \\
-\end{array}$ & $\begin{array}{l}- \\
-\end{array}$ & $\begin{array}{c}0.002 \\
(0.002)\end{array}$ \\
\hline
\end{tabular}


Table 2. (Cont.) Ordered regression predicting good general health status by country of destination (dependent variable is self-perceived health, $1-3,3=$ very good health).

\begin{tabular}{|c|c|c|c|c|c|c|c|c|c|c|c|c|}
\hline \multirow[b]{2}{*}{ Variables } & \multicolumn{3}{|c|}{ Germany } & \multicolumn{3}{|c|}{ France } & \multicolumn{3}{|c|}{ Netherlands } & \multicolumn{3}{|c|}{ Austria } \\
\hline & (1) & (2) & (3) & (1) & (2) & (3) & (1) & (2) & (3) & (1) & (2) & (3) \\
\hline \multicolumn{13}{|l|}{ Constant ${ }^{g}$} \\
\hline Bad Health & $\begin{array}{c}-4.585^{* *} \\
(0.098)\end{array}$ & $\begin{array}{c}-3.991^{* *} \\
(0.157)\end{array}$ & $\begin{array}{c}-4.016^{* *} \\
(0.158)\end{array}$ & $\begin{array}{c}-3.600 * * \\
(0.084)\end{array}$ & $\begin{array}{c}-2.255^{* *} \\
(0.153)\end{array}$ & $\begin{array}{c}-2.251^{* *} \\
(0.153)\end{array}$ & $\begin{array}{c}-3.001^{* *} \\
(0.090)\end{array}$ & $\begin{array}{c}-1.695^{* *} \\
(0.150)\end{array}$ & $\begin{array}{c}-1.684^{* *} \\
(0.150)\end{array}$ & $\begin{array}{c}-4.935^{* *} \\
(0.211)\end{array}$ & $\begin{array}{c}-4.873^{* *} \\
(0.246)\end{array}$ & $\begin{array}{c}-4.873^{* *} \\
(0.246)\end{array}$ \\
\hline Good Health & $\begin{array}{c}-1.905^{* *} \\
(0.083)\end{array}$ & $\begin{array}{c}-1.234^{* *} \\
(0.150)\end{array}$ & $\begin{array}{c}-1.256^{* *} \\
(0.150)\end{array}$ & $\begin{array}{c}-1.233^{* *} \\
(0.074)\end{array}$ & $\begin{array}{c}0.217 \\
(0.151)\end{array}$ & $\begin{array}{c}0.222 \\
(0.151)\end{array}$ & $\begin{array}{c}-0.514^{* *} \\
(0.081)\end{array}$ & $\begin{array}{l}0.896^{* *} \\
(0.149)\end{array}$ & $\begin{array}{l}0.911^{* *} \\
(0.149)\end{array}$ & $\begin{array}{c}-2.849 * * \\
(0.200)\end{array}$ & $\begin{array}{c}-2.733^{* *} \\
(0.237)\end{array}$ & $\begin{array}{c}-2.732^{* *} \\
(0.237)\end{array}$ \\
\hline Observations (non-weighted) & 7,988 & 7,859 & 7,859 & 8,731 & 8,731 & 8,731 & 7,207 & 7,205 & 7,205 & 3,892 & 3,877 & 3,877 \\
\hline Pseudo R-squared & 0.108 & 0.125 & 0.126 & 0.0672 & 0.0924 & 0.0927 & 0.0264 & 0.0507 & 0.0516 & 0.0318 & 0.0469 & 0.0471 \\
\hline
\end{tabular}

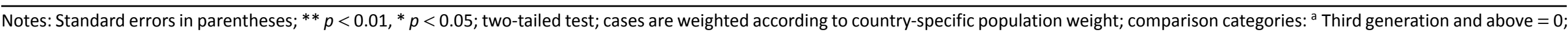

${ }^{\mathrm{b}}$ Female $=0 ;{ }^{\mathrm{c}}$ Middle education $=0 ;{ }^{\mathrm{d}}$ Not in the labor force $=0 ;{ }^{\mathrm{e}}$ Not married $=0 ;{ }^{\mathrm{f}}$ Lives in rural area $=0 ;{ }^{\mathrm{g}}$ Very good health $=3$. 
The reported health of SG does not differ significantly from that reported by TG in all countries, with the exception of Germany. For this country, the negative and significant coefficient for second generation (in all equations) implies that, other things being equal, selfreported health of SG (those born and raised in Germany) is substantially lower than the self-reported health of TG. Apparently, when taking sociodemographic differences between sub-populations into consideration, the health reported by immigrants is significantly lower than the health reported by comparable natives.

Consistent with previous studies, the data show that health tends to decline with age and to rise with education and to be higher among married persons and lower among the unemployed and among those who are not economically active. Interestingly, the effect of gender on health is not consistent across countries. Whereas in Germany males are less likely to report good health, in France and in Austria males report better health than females, and in the Netherlands there are no health differences between the genders.

The GNI of immigrant's country of origin was introduced into model 3 as an indicator of economic conditions to which immigrants were exposed when growing up. It was included in the equation as an interaction term to estimate the impact of country of origin on health disparities between FG and the native-born population (both SG and TG). In Austria, GNI does not exert any net effect on health disparities. In the Netherlands, immigrants' health is likely to increase (or health disparities to decrease) with GNI of country of origin, but in Germany and France, health of FG (as compared to native-born) tends to decrease with GNI of country of origin (as evidenced by the negative coefficients). The differential effects of GNI of country of origin on health disparities between immigrants and native-born might be attributed to qualitative differences between countries that are not captured by GNI, especially differential compositions of the immigrant populations across countries (e.g., Russians and Turks in Germany, North Africans in France, Surinamese in the Netherlands, and Balkans and Turks in Austria). The differential effects of GNI across countries could also reflect variations in in country healthcare systems.

To provide further verification of the country-specific findings, we conducted an additional analysis with all four countries pooled into one data set. The pooled data analysis (results displayed in Table 3 ) corroborates the findings obtained in the country-specific analysis. The data suggest, rather clearly, that across the four countries, FG immigrants are less likely to report good health than TG natives. This is clearly evident by the negative coefficient for FG $(b=-0.349)$. The data also show that reported good health among sons and daughters of immigrants (SG) is lower than TG even after taking sociodemographic differences (as indicated by the negative coefficient $b$ for SG) into consideration. The data further reveal that health of all residents tends to rise with eco- nomic conditions of the host country. The positive and significant effect of GNI of the host country ( $b=0.006$ in models 3 and 4) indicates that, other things being equal, health of all residents (both natives and immigrants) tends to rise with economic resources of the host country (which might be an indicator of quality of healthcare services and facilities).

\section{Discussion and Conclusion}

We embarked on this research in order to examine whether the positive healthy immigrant effect that has been repeatedly observed in the American context (as well as in traditional immigrant societies such as Canada and Australia) prevails in the context of Western European countries. Specifically, we were interested in determining if immigrants to Western Europe are healthier than the comparable native-born populations or, in other words, if they are positively selected on the basis of health. We focused in our study on subjective rather than objective health. Analysis of data from four West European countries (i.e., Germany, France, the Netherlands, and Austria) unequivocally revealed that in all countries the subjective health reported by FG immigrants is significantly lower than the subjective health of the comparable native-born populations. Indeed, this finding contradicts the pattern observed in the United States and is an antithesis to the healthy immigrant effect hypothesis.

The multivariate analysis further reveals, in three of the four countries, that the health of sons and daughters of immigrants (i.e., SG who were born and raised in Europe) is better than the health of the comparable FG immigrants. However, health of the SG is still not as good as that of comparable TG native-born (those natives those natives with very distant or no immigration background). In other words, the subjective health of the offspring of immigrants is higher than that of their parents but still lower than TG natives. Apparently, West European host societies are likely to provide conditions that support attainment of good health for all residents (including the immigrant population but especially that of the native-born populations). The impact of economic resources of the country on health is manifested through the positive impact of GNI of the host country on health of all residents (both immigrants and natives). This finding is consistent with a large number of studies that repeatedly observed that health of the population tends to increase with country's economic resources (Semyonov et al., 2013; Wilkinson \& Pickett, 2008). That is, rich countries are more likely to provide their populations with health services, medical facilities, and advanced treatment that improve the health of the population.

Curiously, whereas economic conditions in the host country affect the health of all persons residing in the country, whether immigrants or native-born, the economic conditions in an immigrant's country of origin (as captured by GNI of country of origin) do not exert any 
Table 3. Ordered regression predicting good general subjective health status, pooled model (dependent variable is selfperceived health, 1-3, 3 = 'very good health').

\begin{tabular}{|c|c|c|c|c|c|c|}
\hline VARIABLES & (1) & (1a) & (2) & (2a) & (3) & (4) \\
\hline \multicolumn{7}{|l|}{ Generation $^{a}$ : } \\
\hline First generation ( = 1) & $\begin{array}{c}-0.349 * * \\
(0.039)\end{array}$ & $\begin{array}{c}-0.419 * * \\
(0.039)\end{array}$ & $\begin{array}{c}-0.235^{* *} \\
(0.040)\end{array}$ & $\begin{array}{c}-0.310^{* *} \\
(0.040)\end{array}$ & $\begin{array}{c}-0.226^{* *} \\
(0.040)\end{array}$ & $\begin{array}{c}-0.227^{* *} \\
(0.040)\end{array}$ \\
\hline Second generation $(=1)$ & $\begin{array}{l}-0.156 * * \\
(0.045)\end{array}$ & $\begin{array}{l}-0.124^{* *} \\
(0.045)\end{array}$ & $\begin{array}{l}-0.133^{* *} \\
(0.045)\end{array}$ & $\begin{array}{r}-0.107^{*} \\
(0.046)\end{array}$ & $\begin{array}{l}-0.118^{* *} \\
(0.046)\end{array}$ & $\begin{array}{l}-0.118 * * \\
(0.046)\end{array}$ \\
\hline Age & $\begin{array}{l}-0.055^{* *} \\
(0.001)\end{array}$ & $\begin{array}{l}-0.050 * * \\
(0.001)\end{array}$ & $\begin{array}{l}-0.044^{* *} \\
(0.001)\end{array}$ & $\begin{array}{l}-0.039 * * \\
(0.001)\end{array}$ & $\begin{array}{l}-0.043^{* *} \\
(0.001)\end{array}$ & $\begin{array}{c}-0.043^{* *} \\
(0.001)\end{array}$ \\
\hline Male $^{b}(=1)$ & - & $\begin{array}{l}- \\
- \\
-\end{array}$ & $\begin{array}{l}0.121 * * \\
(0.024)\end{array}$ & $\begin{array}{l}0.129 * * \\
(0.024)\end{array}$ & $\begin{array}{l}0.120 * * \\
(0.024)\end{array}$ & $\begin{array}{l}0.120^{* *} \\
(0.024)\end{array}$ \\
\hline \multicolumn{7}{|l|}{ Education ${ }^{c}$ : } \\
\hline Lower education ( = 1) & - & - & $\begin{array}{l}-0.284^{* *} \\
(0.030)\end{array}$ & $\begin{array}{l}-0.320 * * \\
(0.032)\end{array}$ & $\begin{array}{l}-0.276^{* *} \\
(0.030)\end{array}$ & $\begin{array}{l}-0.275^{* *} \\
(0.030)\end{array}$ \\
\hline Academic education $(=1)$ & - & - & $\begin{array}{l}0.234^{* *} \\
(0.030)\end{array}$ & $\begin{array}{l}0.292^{* *} \\
(0.030)\end{array}$ & $\begin{array}{l}0.234^{* *} \\
(0.030)\end{array}$ & $\begin{array}{l}0.234^{* *} \\
(0.030)\end{array}$ \\
\hline \multicolumn{7}{|l|}{ Labor force status $^{d}$ : } \\
\hline Unemployed ( = 1) & $\begin{array}{l}- \\
-\end{array}$ & $\begin{array}{l}- \\
-\end{array}$ & $\begin{array}{c}-0.393^{* *} \\
(0.057)\end{array}$ & $\begin{array}{c}-0.289 * * \\
(0.058)\end{array}$ & $\begin{array}{c}-0.388^{* *} \\
(0.057)\end{array}$ & $\begin{array}{c}-0.387^{* *} \\
(0.057)\end{array}$ \\
\hline $\begin{array}{l}\text { Professionals, technicians, } \\
\text { and managers }(=1)\end{array}$ & - & - & $\begin{array}{l}0.609 * * \\
(0.038)\end{array}$ & $\begin{array}{l}0.521^{* *} \\
(0.039)\end{array}$ & $\begin{array}{l}0.610^{* *} \\
(0.038)\end{array}$ & $\begin{array}{c}0.609 * * \\
(0.038)\end{array}$ \\
\hline Clerks $(=1)$ & $\begin{array}{l}- \\
-\end{array}$ & $\begin{array}{l}- \\
-\end{array}$ & $\begin{array}{l}0.378 * * \\
(0.038)\end{array}$ & $\begin{array}{l}0.422^{* *} \\
(0.039)\end{array}$ & $\begin{array}{l}0.375^{* *} \\
(0.038)\end{array}$ & $\begin{array}{c}0.375^{* *} \\
(0.038)\end{array}$ \\
\hline Blue collar ( = 1) & $\begin{array}{l}- \\
-\end{array}$ & $\begin{array}{l}- \\
-\end{array}$ & $\begin{array}{l}0.290 * * \\
(0.041)\end{array}$ & $\begin{array}{l}0.302^{* *} \\
(0.041)\end{array}$ & $\begin{array}{l}0.299 * * \\
(0.041)\end{array}$ & $\begin{array}{c}0.298^{* *} \\
(0.041)\end{array}$ \\
\hline Household size & $\begin{array}{l}- \\
-\end{array}$ & $\begin{array}{l}- \\
-\end{array}$ & $\begin{array}{l}0.028 * * \\
(0.011)\end{array}$ & $\begin{array}{c}0.018 \\
(0.011)\end{array}$ & $\begin{array}{l}0.030 * * \\
(0.011)\end{array}$ & $\begin{array}{c}0.031^{* *} \\
(0.011)\end{array}$ \\
\hline Married $^{\mathrm{e}}(=1)$ & $\begin{array}{l}- \\
-\end{array}$ & $\begin{array}{l}- \\
-\end{array}$ & $\begin{array}{l}0.096 * * \\
(0.028)\end{array}$ & $\begin{array}{l}0.137^{* *} \\
(0.028)\end{array}$ & $\begin{array}{l}0.092^{* *} \\
(0.028)\end{array}$ & $\begin{array}{c}0.092^{* *} \\
(0.028)\end{array}$ \\
\hline Lives in urban $\operatorname{area}^{f}(=1)$ & $\begin{array}{l}- \\
-\end{array}$ & $\begin{array}{l}- \\
-\end{array}$ & $\begin{array}{c}0.032 \\
(0.023)\end{array}$ & $\begin{array}{c}0.010 \\
(0.024)\end{array}$ & $\begin{array}{c}0.047^{*} \\
(0.024)\end{array}$ & $\begin{array}{c}0.048^{*} \\
(0.024)\end{array}$ \\
\hline GNI rank: country of destination & $\begin{array}{l}- \\
-\end{array}$ & $\begin{array}{l}- \\
-\end{array}$ & - & - & $\begin{array}{l}0.006^{* *} \\
(0.002)\end{array}$ & $\begin{array}{c}0.006^{* *} \\
(0.002)\end{array}$ \\
\hline $\begin{array}{l}\text { GNI rank: country of birth } \\
\text { (centered) } * \text { Generation } 1\end{array}$ & - & - & - & - & - & $\begin{array}{c}0.001 \\
(0.001)\end{array}$ \\
\hline \multicolumn{7}{|l|}{ Country of destination $\mathrm{g}$ : } \\
\hline France $(=1)$ & - & $\begin{array}{l}0.104^{* *} \\
(0.030)\end{array}$ & - & $\begin{array}{l}0.157^{* *} \\
(0.032)\end{array}$ & - & - \\
\hline Netherlands ( = 1) & - & $\begin{array}{l}0.331 * * \\
(0.031)\end{array}$ & - & $\begin{array}{l}0.353^{* *} \\
(0.034)\end{array}$ & - & - \\
\hline Austria ( = 1) & - & $\begin{array}{l}0.813^{* *} \\
(0.040)\end{array}$ & - & $\begin{array}{l}0.829 * * \\
(0.041)\end{array}$ & - & - \\
\hline \multicolumn{7}{|l|}{ Constant $^{\mathrm{h}}$ : } \\
\hline Bad Health & $\begin{array}{l}-3.987^{* *} \\
(0.048)\end{array}$ & $\begin{array}{l}-3.548^{* *} \\
(0.053)\end{array}$ & $\begin{array}{l}-3.038^{* *} \\
(0.080)\end{array}$ & $\begin{array}{l}-2.594 * * \\
(0.083)\end{array}$ & $\begin{array}{l}-1.901 * * \\
(0.375)\end{array}$ & $\begin{array}{l}-1.884^{* *} \\
(0.375)\end{array}$ \\
\hline Good Health & $\begin{array}{c}-1.579 * * \\
(0.041)\end{array}$ & $\begin{array}{l}-1.109 * * \\
(0.048)\end{array}$ & $\begin{array}{l}-0.554^{* *} \\
(0.078)\end{array}$ & $\begin{array}{c}-0.081 \\
(0.082)\end{array}$ & $\begin{array}{c}0.583 \\
(0.374)\end{array}$ & $\begin{array}{c}0.600 \\
(0.375)\end{array}$ \\
\hline Observations (non-weighted) & 27,818 & 27,672 & 27,818 & 27,672 & 27,672 & 27,672 \\
\hline Pseudo R-squared & 0.0972 & 0.131 & 0.103 & 0.137 & 0.132 & 0.132 \\
\hline
\end{tabular}

Notes: Standard errors in parentheses; ${ }^{* *} p<0.01,{ }^{*} p<0.05$; two-tailed test; cases are weighted according to country-specific population weight; comparison categories: ${ }^{\mathrm{a}}$ Third generation and above $=0 ;{ }^{\mathrm{b}}$ Female $=0 ;{ }^{\mathrm{c}}$ Middle education $=0 ;{ }^{\mathrm{d}}$ Not in the labor force $=0$; ${ }^{\mathrm{e}}$ Not married $=0 ;{ }^{\mathrm{f}}$ Lives in rural area $=0 ;{ }^{\mathrm{g}}$ Germany $=0 ;{ }^{\mathrm{h}}$ Very good health $=3$. 
systematic impact on the size of the health disparities between immigrants and natives. In the Netherlands, immigrants' subjective health tends to increase with GNI of country of origin but the health of immigrants from advanced economies to France and Germany tends to be lower. Yet in Austria, the GNI of country of origin has no impact on health of immigrants. This is probably due to differential selection systems that operate in the sorting process of immigrants from a specific country of origin into a specific country of destination. Indeed, the selection process is influenced by the unique conditions associated with both country of origin and country of destination. Furthermore, the insignificant effect of the GNI of the country of origin on the subjective health of FG immigrants may also be attributed to the fact that most immigrants originated from poor countries, where better GNI values do not necessarily correspond in a systematic way with better health services. In addition, many of FG immigrants have lived for quite a long period of time in the countries of destination, and the current GNI of country of origin may not necessarily correspond with the GNI level at the time they had immigrated. Indeed, it is possible that in addition to 'healthy immigrants,' some immigrants are attracted to the good and accessible healthcare system in Western Europe, while some may arrive as refugees and asylum seekers. Therefore, not only differences in patterns of positive health selection but also patterns of negative migration or return migration (i.e., salmon-bias effect) may differ considerably between the United States and West European countries.

In sum, the findings reported here reveal that the patterns of health disparities between immigrants and native-born in the four West European countries differ dramatically from those observed in the United States. Contrary to theoretical expectations (as derived from the healthy immigrant thesis), in all four countries immigrants are not healthier than the native-born populations. In fact, other things being equal, immigrants report lower subjective health than the native-born population in all four European countries. The difference can be attributed, first and foremost, to differences in immigrants' admission policies and differences in healthcare policies between the United States and Western Europe. The United States (and other traditional immigrant societies such as Canada and Australia) utilizes health status as one of the major criteria for (legal) admission of immigrants to the country (much more so than in Western Europe). In addition, in the United States, healthcare services are much more expensive and less accessible than the care facilities in most West European countries. Therefore, health considerations and health criteria play a much greater role in positive self-selection and in admission of immigrants into the United States than in Europe. The accessible health services in Europe may also result in healthier domestic populations (considerably healthier than the American population; Maskileyson, 2014). As a result, whereas an av- erage immigrant in Europe is not healthier than the comparable average native-born European, the average immigrant to the United States is healthier than the average native-born American. It is possible, of course, that health disparities between immigrants and native-born Europeans would further increase due to the recent influx of refugees to Europe and the associated change in the composition of the foreign-born population; a possibility with implications that should be taken into consideration not only in future studies but also by policy makers.

Although this research has succeeded in achieving its aims, several limitations need to be borne in mind when interpreting our findings. First, whereas subjective health measures are good predictors of life expectancy and correlate with objective health measures, it remains to be answered whether and to what extent findings in these countries remain similar when objective health measures are used. Second, it is unclear whether the observed differences in self-perceived health within and across countries reflect true differences or whether they merely reflect cultural bias in the measures (Snowden, 2003). Indeed, most measures of health assessment have been initially developed and tested on samples comprised largely of culturally homogeneous groups (e.g., European-American populations with native English-speaking abilities). Consequently, subjective health questions translated into various languages may not be understood in the same way when applied to different cultures (Teresi, 2006). Specifically, measurement nonequivalence might lead to biased conclusions about similarities and differences in health measures of different groups within and across countries. Several recent studies demonstrated that evidence of the cultural equivalence of health-related measures is sparse (Grol-Prokopczyk, Verdes-Tennant, McEniry, \& Ispány, 2015; Hardy, Acciai, \& Reyes, 2014). Although subjective measures may generate a problem of comparability across countries (see Davidov, Meuleman, Cieciuch, Schmidt, \& Billiet, 2014), using three broad categories of subjective health as done in the current study was likely to reduce this problem. In addition, since we have only a single measured indicator of health, we could not test its comparability across groups and countries. Third, the reason for migration can be another factor that has a differential impact of immigrants' health. Several studies confirm that forced migrants represent a disadvantaged group, not only in comparison to the native-born population, but also in comparison to other economic and noneconomic immigrants (Hugo, Abbasi-Shavazi, \& Kraly, 2017). Indeed, refugees tend to have less command of the local language, less educational experience, less access to family support, and poorer mental and physical health (Hugo et al., 2017). Unfortunately, individuallevel indicators on refugee status were not available in the present data to examine the issue. Nevertheless, it should be noted that only about $1 \%$ of the FG and SG immigrants in the sample under study were from countries 
with highly oppressive regimes (e.g., former Yugoslavia, Iran, Iraq, and Afghanistan). In future research we would like to see the further examination of the reason for migration and the impact of refugee status on health. Likewise, we do hope that future investigations would benefit from the use of longitudinal and panel data analysis, and of multiple measures of subjective and objective health, in studying health disparities between nativeborn and immigrants in a comparable way. Despite the limitations of the data, however, the findings of the present research do underscore the importance of the host country and its unique context in the study of health disparities between immigrants and the native-born population across countries.

\section{Acknowledgments}

The authors would like to thank Professor Yitchak Haberfeld and Professor Peter Schmidt for their useful comments and suggestions and Lisa Trierweiler for the English proofreading of the manuscript.

\section{Conflict of Interests}

The authors declare no conflict of interests.

\section{References}

Abraído-Lanza, A. F., Dohrenwend, B. P., Ng-Mak, D. S., \& Turner, J. B. (1999). The Latino mortality paradox: A test of the "salmon bias" and healthy migrant hypotheses. American Journal of Public Health, 89(10), 1543-1548.

Acevedo-Garcia, D., Bates, L. M., Osypuk, T. L., \& McArdle, N. (2010). The effect of immigrant generation and duration on self-rated health among US adults 2003-2007. Social Science and Medicine, 71(6), 1161-1172.

Akresh, I. R., \& Frank, R. (2008). Health selection among new immigrants. American Journal of Public Health, 98(11), 2058-2064.

Arenas, E., Goldman, N., Pebley, A. R., \& Teruel, G. (2015). Return migration to Mexico: Does health matter? Demography, 52(6), 1853-1868.

Biddle, N., Kennedy, S., \& McDonald, J. T. (2007). Health assimilation patterns amongst Australian immigrants. Economic Record, 83(260), 16-30.

Boulogne, R., Jougla, E., Breem, Y., Kunst, A. E., \& Rey, G. (2012). Mortality differences between the foreign-born and locally-born population in France (2004-2007). Social Science and Medicine, 74(8), 1213-1223.

CDC. (2014) Technical instructions for panel physicians. Centers for Disease Control and Prevention. Retrieved from http://www.cdc.gov/immigrantrefugee health/exams/ti/panel/technical-instructions-panelphysicians.html

Constant, A. F., García-Muñoz, T., Neuman, S., \& Neu- man, T. (2015). A "healthy immigrant effect" or a "sick immigrant effect"? Selection and policies matter (IZA Discussion Paper No. 9338). Bonn: Forschungsinstitut zur Zukunft der Arbeit (IZA). Retrieved from http://ftp.iza.org/dp9338.pdf

Cunningham, S. A., Ruben, J. D., \& Narayan, K. V. (2008). Health of foreign-born people in the United States: A review. Health and Place, 14(4), 623-635.

Darmon, N., \& Khlat, M. (2001). An overview of the health status of migrants in France, in relation to their dietary practices. Public Health Nutrition, 4(02), 163-172.

Davidov, E., Meuleman, B., Cieciuch, J., Schmidt, P., \& Billiet, J. (2014). Measurement equivalence in crossnational research. Annual Review of Sociology, 40, 55-75.

Eikemo, T. A., Bambra, C., Joyce, K., \& Dahl, E. (2008). Welfare state regimes and income-related health inequalities: A comparison of 23 European countries. The European Journal of Public Health, 18(6), 593-599.

Elkeles, T., \& Seifert, W. (1996). Immigrants and health: Unemployment and health-risks of labour migrants in the Federal Republic of Germany, 1984-1992. Social Science and Medicine, 43(7), 1035-1047.

Ferraro, K. F., \& Farmer, M. M. (1999). Utility of health data from social surveys: Is there a gold standard for measuring morbidity? American Sociological Review, 64(2), 303-315.

Fokkema, T., Kveder, A., Hiekel, N., Emery, T., \& Liefbroer, A. C. (2016). Generations \& Gender Programme wave 1 data collection: An overview and assessment of sampling and fieldwork methods, weighting procedures, and cross-sectional representativeness. Demographic Research, 34, 499-524.

Frisbie, W. P., Cho, Y., \& Hummer, R. A. (2001). Immigration and the health of Asian and Pacific Islander adults in the United States. American Journal of Epidemiology, 153(4), 372-80.

GGS. (n.d.). Generations \& Gender Programme: A social science infrastructure for research on family dynamics and relationships. GGS. Retrieved from http:// www.ggp-i.org

Goldman, N., Pebley, A. R., Creighton, M. J., Teruel, G. M., Rubalcava, L. N., \& Chung, C. (2014). The consequences of migration to the United States for shortterm changes in the health of Mexican immigrants. Demography, 51(4), 1159-1173.

Grol-Prokopczyk, H., Verdes-Tennant, E., McEniry, M., \& Ispány, M. (2015). Promises and pitfalls of anchoring vignettes in health survey research. Demography, 52(5), 1703-1728.

Guendelman, S., \& Abrams, B. (1995). Dietary intake among Mexican-American women: Generational differences and a comparison with white non-Hispanic women. American Journal of Public Health, 85(1), 20-25.

Guendelman, S., Gould, J. B., Hudes, M., \& Eskenazi, B. 
(1990). Generational differences in perinatal health among the Mexican American population: Findings from HHANES 1982-1984. American Journal of Public Health, 80, 61-65.

Hardy, M. A., Acciai, F., \& Reyes, A. M. (2014). How health conditions translate into self-ratings: A comparative study of older adults across Europe. Journal of Health and Social Behavior, 55(3), 320-341.

Hugo, G., Abbasi-Shavazi, M. J., \& Kraly, E. P. (Eds.). (2017). Demography of refugee and forced migration (Vol. 13). Cham: Springer.

Jasso, G., Massey, D. S., Rosenzweig, M. R., \& Smith, J. P. (2004). Immigrant health: Selectivity and acculturation. In N. B. Anderson, R. A. Bulatao, \& B. Cohen (Eds.), Critical perspectives on racial and ethnic differences in health in late life (pp. 227-266). Washington, DC: National Academy Press.

Kennedy, S., McDonald, J. T., \& Biddle, N. (2006). The healthy immigrant effect and immigrant selection: Evidence from four countries. Social and Economic Dimensions of an Aging Population Research Papers, 2006(164). Retrieved from https://ideas.repec.org/ $\mathrm{p} / \mathrm{mcm} / \mathrm{sedapp} / 164 . \mathrm{html}$

Kennedy, S., Kidd, M. P., McDonald, J. T., \& Biddle, N. (2015). The healthy immigrant effect: Patterns and evidence from four countries. Journal of International Migration and Integration, 16(2), 317-332.

Laumann, E. O., Paik, A., \& Rosen, R. C. (1999). Sexual dysfunction in the United States: Prevalence and predictors. JAMA, 281(6), 537-544.

Lu, Y., \& Qin, L. (2014). Healthy migrant and salmon bias hypotheses: A study of health and internal migration in China. Social Science \& Medicine, 102, 41-48.

Martinez, J. N., Aguayo-Tellez, E., \& Rangel-Gonzalez, E. (2015). Explaining the Mexican-American health paradox using selectivity effects. International Migration Review, 49(4), 878-906.

Maskileyson, D. (2014). Healthcare system and the wealth-health gradient: A comparative study of older populations in six countries. Social Science and Medicine, 119, 18-26.

McDonald, J. T., \& Kennedy, S. (2004). Insights into the 'healthy immigrant effect': Health status and health service use of immigrants to Canada. Social Science and Medicine, 59(8), 1613-1627.

Mehta, N. K., \& Elo, I. T. (2012). Migrant selection and the health of US immigrants from the former Soviet Union. Demography, 49(2), 425-447.

Organization for Economic Co-operation and Development. (2016). Statistics database: Health statisticsHealth Expenditure. OECD Stat. Retrieved from https://stats.oecd.org/Index.aspx?\%20DatasetCode =HEALTH_STAT

Organization for Economic Co-operation and Development. (2019). International migration outlook 2016. Paris: OECD Publishing.

$\emptyset$ stbye, T., Krause, K. M., Norton, M. C., Tschanz, J., Sanders, L., Hayden, K., . . . Cache County Investiga- tors. (2006). Ten dimensions of health and their relationships with overall self-reported health and survival in a predominately religiously active elderly population: The cache county memory study. Journal of the American Geriatrics Society, 54(2), 199-209.

Palloni, A., \& Arias, E. (2004). Paradox lost: Explaining the Hispanic adult mortality advantage. Demography, 41(3), 385-415.

Razum, O., \& Rohrmann, S. (2002). The healthy migrant mortality effect: Role of selection and late entry bias. Atherosclerosis, 64(2), 82-88.

Razum, O., Zeeb, H., Akgün, H. S., \& Yilmaz, S. (1998). Low overall mortality of Turkish residents in Germany persists and extends into a second generation: Merely a healthy migrant effect? Tropical Medicine and International Health, 3(4), 297-303.

Riosmena, F., Wong, R., \& Palloni, A. (2013). Migration selection, protection, and acculturation in health: A binational perspective on older adults. Demography, 50(3), 1039-1064.

Ronellenfitsch, U., \& Razum, O. (2004). Deteriorating health satisfaction among immigrants from Eastern Europe to Germany. International Journal for Equity in Health, 3(4). Retrieved from https://equityhealthj. biomedcentral.com/track/pdf/10.1186/1475-92763-4

Sardadvar, S. (2015). How migrant status affects health beyond socioeconomic status: Evidence from Austria. International. Migration Review, 49(4), 843-877.

Semyonov, M., Lewin-Epstein, N., \& Maskileyson, D. (2013). Where wealth matters more for health: The wealth-health gradient in 16 countries. Social Science and Medicine, 81, 10-17.

Singh, G. K., \& Siahpush, M. (2002). Ethnic-immigrant differentials in health behaviors, morbidity, and causespecific mortality in the United States: An analysis of two national data bases. Human Biology, 1, 83-109.

Snowden, L. R. (2003). Bias in mental health assessment and intervention: Theory and evidence. American Journal of Public Health, 93(2), 239-243.

Teresi, J. A. (2006). Overview of quantitative measurement methods: Equivalence, invariance, and differential item functioning in health applications. Medical Care, 44(11), S39-S49.

Turra, C. M., \& Elo, I. T. (2008). The impact of salmon bias on the Hispanic mortality advantage: New evidence from social security data. Population Research and Policy Review, 27(5), 515-530.

UNESCO Institute for Statistics. (2012). International standard classification of education: ISCED 2011. Montreal: UNESCO Institute for Statistics.

United Nations. (2005). Generations \& Gender Programme: Survey instruments. Geneva and New York, NY: UN.

Wallace, M., \& Kulu, H. (2014). Low immigrant mortality in England and Wales: A data artefact? Social Science \& Medicine, 120, 100-109.

Wilkinson, R. G., \& Pickett, K. E. (2008). Income inequality 
and socioeconomic gradients in mortality. American Journal of Public Health, 98(4), 699-704.

Williams, S. R., Pham-Kanter, G., \& Leitsch, S. A. (2009). Measures of chronic conditions and diseases associated with aging in the national social life, health, and aging project. The Journals of Gerontology Se- ries B: Psychological Sciences and Social Sciences, 64(1), 67-75.

World Bank Group. (Ed.). (2014). World development indicators database, 2014. Washington, DC: World Bank Publications.

\section{About the Authors}
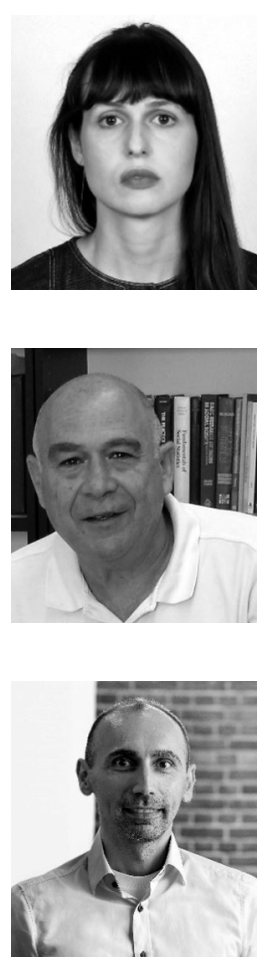

Dina Maskileyson is Postdoctoral Researcher at the Institute of Sociology and Social Psychology at the University of Cologne. Her research interests lie in the areas of immigration, health, and labor market and wealth inequality. Her recent publications focus on immigrants' labor market integration as well as health trajectories of immigrants after the arrival to the host country.

Moshe Semyonov is Professor Emeritus of Sociology and Labor Studies at Tel Aviv University and Professor Emeritus of Sociology at the University of Illinois at Chicago. Semyonov's research interests lie in the areas of comparative stratification and inequality and causes and consequences of global migration. His recent publications deal with inequality in a comparative perspective, integration of immigrants in the labor market and attitudes toward immigrants across space and time.

Eldad Davidov is Professor at the Institute for Sociology and Social Psychology at the University of Cologne, Germany, and the Department of Sociology at the University of Zurich, Switzerland, and codirector of the University of Zurich Research Priority Program "Social Networks." He was president of the European Survey Research Association (ESRA) between 2015 and 2017. His research interests are applications of structural equation modeling to survey data, especially in cross-cultural and longitudinal research. Applications include human values, national identity, and attitudes toward immigrants and other minorities. 


\section{COGITATIO}

Annex

Table A1. Measurement and response categories of variables.

\begin{tabular}{|c|c|c|c|}
\hline \multirow[b]{2}{*}{ Variable } & \multirow[b]{2}{*}{ Measurement } & \multicolumn{2}{|c|}{ Responses Range } \\
\hline & & Min & Max \\
\hline General health status & Fair, bad, very bad $=1 ;$ Good $=2 ;$ Very good $=3$ & 1 & 3 \\
\hline Generation & $\begin{array}{l}\text { First generation }=1 \text {; Second generation }=1 ; \\
\text { Third generation and above }=0\end{array}$ & 0 & 1 \\
\hline Gender & Male $=1 ;$ Female $=0$ & 0 & 1 \\
\hline Age of respondent & In years & 26 & 82 \\
\hline Education & $\begin{array}{l}\text { Lower education }=1 ; \text { Academic education }=1 \text {; } \\
\text { Middle education }=0\end{array}$ & 0 & 1 \\
\hline Labor force status & $\begin{array}{l}\text { Unemployed }=1 ; \text { Professionals, technicians, } \\
\text { and managers }=1 ; \text { Clerks }=1 ; \text { Blue collar occupations }=1 \text {; } \\
\text { Not in the labor force }=0\end{array}$ & 0 & 1 \\
\hline $\begin{array}{l}\text { Household size including } \\
\text { respondent }\end{array}$ & Number of persons & 1 & 13 \\
\hline Marital status & Married $=1 ;$ Not married $=0$ & 0 & 1 \\
\hline Area of living & Lives in urban area $=1$; Lives in rural area $=0$ & 0 & 1 \\
\hline $\begin{array}{l}\text { Gross national income per capita, } \\
\text { PPP, ranking of country of birth } \\
\text { (World Bank Group, 2014) }\end{array}$ & In rank points, higher value indicates higher rank & 1 & 200 \\
\hline $\begin{array}{l}\text { Gross national income per capita, } \\
\text { PPP, ranking of country of destination } \\
\text { (World Bank Group, 2014) }\end{array}$ & In rank points, higher value indicates higher rank & 172 & 186 \\
\hline
\end{tabular}

\section{Reference}

World Bank Group. (Ed.). (2014). World development indicators database, 2014. Washington, DC: World Bank Publications. 